\title{
A SZÓVÉGI -S KIESÉSÉNEK PROBLÉMÁJA A LATIN FELIRATOK TÜKRÉBEN"
}

\begin{abstract}
Jelen tanulmány, Herman József vonatkozó munkásságához kapcsolódva, a szóvégi -s kiesésének, törlésének problémájával foglalkozik a latin feliratos anyag tükrében. A Császárkori latin feliratok számítógépes nyelvtörténeti adatbázisában rögzített szóvégi -s kiesések elemzésével e dolgozat a Herman József által javasolt morfoszintaktikai magyarázatot kívánja helyettesíteni egy fonetikai, fonoszintaktikai értelmezéssel, amely rávilágít a mássalhangzói környezet döntő fontosságára a szóvégi -s mindenkori kiesésében, törlésében. Eszerint a szóvégi -s fonoszintaktikailag meghatározott törlése rákövetkező mássalhangzó előtt folyamatosan megvolt, de különböző mértékben jelentkezett az ólatin korszaktól kezdve mindvégig a latin nyelv történetének folyamán. Ezt a helyzetet örökölhették meg az újlatin/román nyelvek, amelyekben különböző irányú, komplex morfológiai újítások vezethettek a fonoszintaktikailag meghatározott $s$-törlés megszűnéséhez és a szóvégi - $s$ stabilizációjához (amint ez az ún. nyugati újlatin/román nyelvekben bekövetkezett) vagy kiteljesedéséhez és a szóvégi - $s$ teljes eltűnéséhez (ahogy ez az ún. keleti típusú újlatin/román nyelvekben történt).
\end{abstract}

Kulcsszavak: feliratok, fonológia, szóvégi mássalhangzók, ólatin, vulgáris latin, nyugati és keleti újlatin/román nyelvek

1. Kiindulásképpen idézzük fel Herman József Vulgáris latin című alapművének a szóvégi mássalhangzók változásait tárgyaló részét, ahol a szóvégi - $m$ ingatag helyzetének, majd eltűnésének rövid bemutatását követően ezt olvashatjuk a szóvégi -s történetéről:

„A többi mássalhangzó közül megemlítendők a szóvégi $-s$ és - $t$, amelyek szintén gyengülni látszanak. Az archaikus feliratokon elég gyakran elmarad az $-s$, de később visszaállt a helyesírásban, ami minden bizonnyal a kiejtést tükrözte, hiszen az újlatin nyelvek nagy része a mai napig megőrizte a latin $s$-t (gondolunk az iberoromán nyelvekre, pl. spanyol pl. hijos < latin filios, quieres < latin quaeris [quaerere 'keresni, kérdezni' alakja], dos < duos 'kettő' stb.; ez történik a galloromán esetében is, bár a mai francia csak a szavak kötésekor [liaison] őrzi az $s$ nyomát - pl. [z]-t egy grands hommes-típusú szókapcsolatban -, valamint természetesen a helyesírásban). Az olasz nyelvjárások nagy részéből és a románból kiveszett az -s, de ez későbbre, talán az első évezred második felére tehető. A jelenség részletei nem világosak; szokás Cicero állítására hivatkozni (Orator 161), mely szerint az ő korában a helyes beszédben kötelező volt az $-s$ ejtése, még olyan helyzetekben is, amelyekben az archaikus auktorok eltürték az elmaradását; ha hiszünk a falfeliratoknak, az -s stabil volt a pompeji köznyelvben, és későbbi elmara-

* Jelen tanulmány az NKFIH (OTKA) K 108399 és 124170 ny. sz. „Császárkori latin feliratok számítógépes nyelvtörténeti adatbázisa” (3. és 4. szakasz) című projektje keretében az MTA 'Lendület' Számítógépes Latin Dialektológiai Kutatócsoportban készült. 
dása a vulgáris jellegű feliratokon szintén összehasonlíthatatlanul szórványosabb, mint az - $m$ elhagyása. Csak az V. és VI. századtól kezdve növekszik jelentősen a feliratos példák gyakorisága, különösen az itáliai keresztény feliratokon és kiváltképp a rómaiakon: ez a kezdete az újlatin nyelvek későbbi differenciálódásának, amelyek sorában megkülönböztetjük a szóvégi -s hangot megtartó, illetve elejtő nyelveket."

E jellegzetes nyelvföldrajzi megoszlást jól példázzák a következő megfelelések, a latin 'három' és 'mi' jelentésű szavak folytatásai: REW n. 8883 „trēs, drei”. Rum. trei, vegl. tra, it. tre, log. tres, engad. trais, friaul. tre, frz. trois, prov., kat., sp., pg. tres; és REW n. 5960 „nōs, wir”. Rum. noŭ, vegl., it. noi, log. nos, engad. nus, friaul. nus, frz. nous, prov., kat., sp., pg. nos. A keleti és a nyugati újlatin/román nyelvek közötti (többé-kevésbé sematikus, a valós viszonyokat némileg leegyszerüsítő) határvonal e tekintetben, mint oly sok más vonatkozásban is, az úgynevezett Massa-Senigallia- (korábban La Spezia-Rimini-) vonal mentén futott, ahogy azt az $1 a$. térkép is ábrázolja. ${ }^{2}$

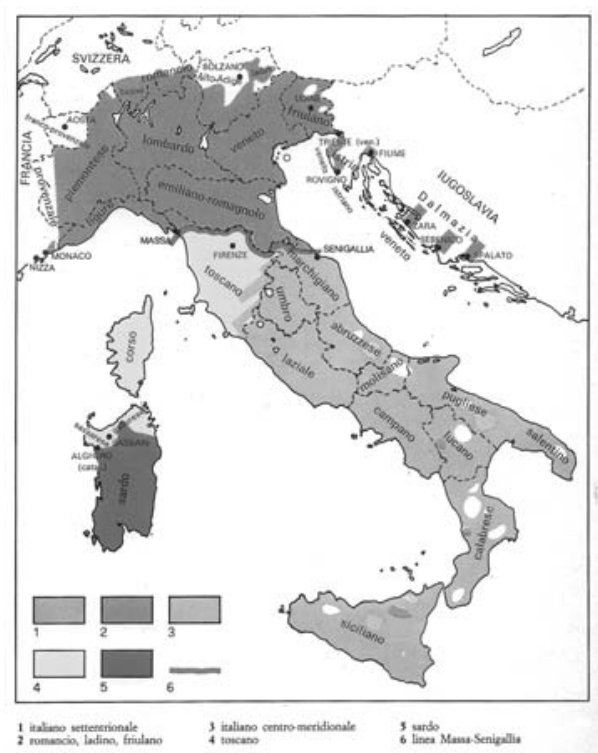

1a. ábra. Massa-Senigallia- =

La Spezia-Rimini-vonal

Tav. VII: 'Il dominio italo-romanzo'

In: Renzi-Salvi: i. m. (2. jegyz.)

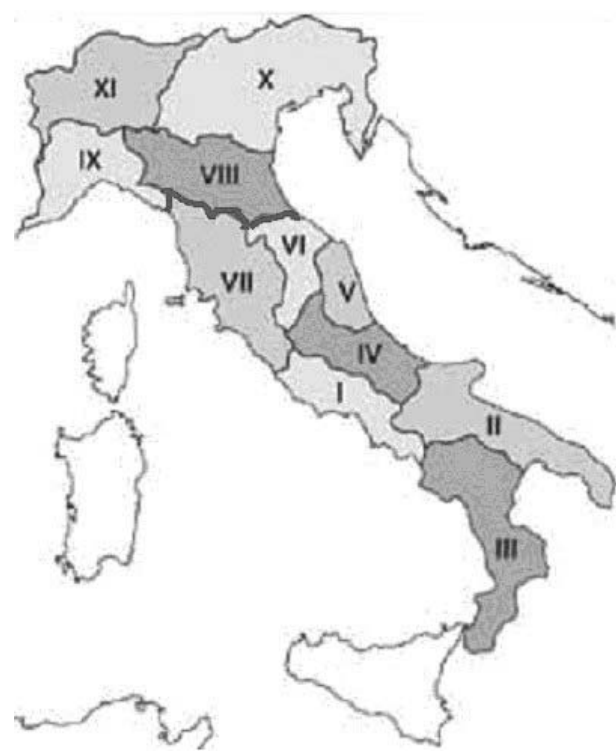

1b. ábra. Itália régiói Augustus korában Észak-Itália = Aemilia VIII, Liguria IX, Venetia et Histria X, Transpadana XI;

Közép- és Dél-Itália = Latium et Campania I, Apulia et Calabria II, Bruttium et Lucania III,

Samnium IV, Picenum V, Umbria VI, Etruria VII

1 Herman J.: Vulgáris latin. Az újlatin nyelvek kialakulásának útja. Budapest 2003. 39; angol megfelelőjét vö. J. Herman: Vulgar Latin. University Park Pennsylvania 2000. 40 sk.

2 REW = W. Meyer-Lübke: Romanisches etymologisches Wörterbuch. Heidelberg $1935^{2}$. Az 1a. térkép forrása: L. Renzi - G. Salvi: Nuova introduzione alla filologia romanza. Bologna 1985. 
Az $1 b$. térkép viszont azt mutatja, hogy ez az újlatin/román nyelvföldrajzi választóvonal lényegében egybeesik az ókori Liguria (regio IX), Aemilia (regio VIII) és Etruria (regio VII), Umbria (regio VI) közötti határvonallal. ${ }^{3}$

2. Herman József a szóvégi -s problémájával nemcsak általánosságban foglalkozott a méltán híres Vulgáris latin címü könyvében, hanem külön tanulmányt is szentelt a feliratokon megfigyelhető szóvégi $s$-kiesések magyarázatának. ${ }^{4}$ Ebben Herman azt a következtetést vonta le, hogy a császárkori latin feliratokról rögzíthető szóvégi $s$-leesések inkább magyarázhatók morfoszintaktikai változásokkal, mint hangtani fejleményekkel. A tisztán hangtani magyarázat ellen Herman azt hozta fel érvként, ${ }^{5}$ hogy a szóvégi $s$-leesések gyakorisága jóval az elvárható szint alatt marad, amennyiben más, egyértelműen fonetikai hátterű változásokkal vetjük egybe, mint amilyenek a $b$ és $w$ fúziója okozta $B / V$-keverések ${ }^{6}$ vagy a szóvégi $m$-leesések gyakori esetei. A szóvégi $s$-kiesések ez utóbbihoz, tehát a szóvégi $m$-leesésekhez képesti ritkaságára Herman a Vulgáris latin fent idézett részében is tett utalást. Emellett Herman arra is felhívta a figyelmet, hogy az afrikai Hadrumetumban talált, II-III. századi átoktáblákon a szóvégi $s$-kiesés igen gyakran -us végü névszók, főként tulajdonnevek nominativusi alakjában jelentkezik, és ebből arra következtetett, hogy a helyi latin nyelvben az $-u(s)$ nominativusok összekeverhetővé és felcserélhetővé váltak az $-u(m)$ accusativusokkal, legalábbis a nominativus funkcióiban. ${ }^{7}$ Ezt a folyamatot, illetve e folyamat eredményét olyan furcsa mondatok példázzák, mint Latrone, Vagulu cadant, amely a (helyes) Latro, Vagulus cadant ('Latro és Vagulus bukjon el') és a (helytelen) Latronem Vagulum cadant mondatok keresztezésével jöhetett létre az említett módon. Ehhez az érdekes szövegcsoporthoz és Herman-féle értelmezésükhöz később még visszatérünk.

Herman morfoszintaktikai magyarázata ezt a jelenséget annak a folyamatnak a kezdetén helyezte el, ${ }^{8}$ amelyik - az accusativusnak a nominativusra történő funkcionális kiterjedésével beindulva - végül ahhoz vezetett, hogy az afrikai latinságban az accusativus lett az alapeset, avagy egyetlen eset a névszóragozásban - szemben pl. a galloromán fejlődéssel, ahol megmaradt a nominativusi -s és a két külön eset. Herman értelmezését

3 Ennek az egybeesésnek itt és most annyi a következménye, hogy a későbbiekben a latin nyelvföldrajzi viszonyok tárgyalásánál erre a megoszlásra tekintettel leszünk.

4 J. Herman: La disparition de $-s$ et la morphologie dialectale du latin parlé. In: Latin vulgaire et latin tardif I. Ed. J. Herman. Tübingen 1987. 97-108. = J. Herman: Du latin aux langues romanes II. Nouvelles études de linguistique historique. (réun. S. Kiss). Tübingen 2006. 33-42.

5 Vö. Herman: i. m. (4. jegyz.) 35 és 37.

6 Mint pl. INCOMPARAVILI = incomparabili, vö. LLDB-42247. A továbbiakban a Császárkori latin feliratok számítógépes nyelvtörténeti adatbázisára (vö. http://lldb.elte.hu/) adatbázisként vagy LLDB rövidítéssel, adatlapjaira pedig az LLDB-számmal hivatkozunk.

7 Vö. Herman: i. m. (4. jegyz.) 36, 39 sk.

8 Vö. Herman: i. m. (4. jegyz.) 41. 
viszonylag pozitívan fogadta a szakirodalom, Adams például így nyilatkozott róla: „Lehet valami ebben az ötletben." ${ }^{9}$

Jelen dolgozat ezt a Herman-féle morfoszintaktikai magyarázatot kívánja górcső alá venni, mégpedig a Római Birodalom nyugati (Afrikát is magába foglaló) latin felének feliratos anyagára támaszkodva, hiszen Herman szerint a Birodalom más területein jelentkező, nyelvileg releváns szóvégi $s$-leesések is ugyanazzal a morfoszintaktikai ingadozással magyarázandók, mint az afrikai, hadrumetumi átoktáblák esetei.

Egy ilyen vizsgálatot már csak azért is érdemes a Birodalom egész latin felére kiterjeszteni, mert előzetes vizsgálataink arra mutatnak, hogy a latin Afrikán kívüli területekről származó szóvégi $s$-leesések nehezen magyarázhatók morfoszintaktikai tényezőkkel vagy legalábbis az accusativusnak a nominativusra történő funkcionális kiterjedésével. A nominativus és accusativus közötti keverések ugyanis rendkívül ritkák a vizsgált anyagban, ${ }^{10}$ különösen, ha az accusativus és ablativus közötti keverések jelentős gyakoriságához mérjük őket (lásd lentebb). ${ }^{11}$

Ez a helyzet késztet bennünket arra, hogy a Császárkori latin feliratok számítógépes nyelvtörténeti adatbázisában rögzített összes szóvégi $s$-leesést elemezzük, különös tekintettel az - $u$ utániakra, és ne csak területi és időbeli megoszlásukat, hanem a hangtani környezetüket is vizsgálat tárgyává tegyük, és ezzel a fonetikai vagy fonoszintaktikai megközelítésű értelmezést újra beemeljük a szakirodalomba a morfoszintaktikai magyarázat mellé vagy annak helyére.

3. Ebbe az elemzésbe bevontuk a Birodalom teljes latin részét, így több mint 40 provinciának az adatbázisban eddig feldolgozott anyagán tudtuk a vizsgálatot elvégezni. ${ }^{12}$ Az időbeli változások nyomon követhetősége végett, és alkalmazkodva a feliratos gyüjtemények keltezési gyakorlatához (amennyiben sokszor csak a keresztény korra és az azt megelőző, nem keresztény, avagy pogány korra szokták a császárkori feliratokat keltezni), a releváns anyagot két korszakra osztottuk: korai korszakra (I-III. század) és kései korszakra (IV-VII. század). ${ }^{13}$ Az 1 . táblázat diagramjai mutatják a mássalhangzórendszer

9 „There may be something in this idea”, vö. J. N. Adams: Social variation and the Latin language. Cambridge 2013. 143.

10 Pl. LLDB-43687: HIC REQVI|ISCIT ALBINVM EPISCOPVM = hic requiescit Albinus episcopus vagy LLDB-46856: P SIGERIVS = per Sigerium.

11 Pl. LLDB-8547: PER VALERIO = per Valerium vagy LLDB-1235 EX VOTVM = ex voto.

12 Az adatlapokat a 2017. 06. 15 szerinti állapot szerint vettük figyelembe. Az érintett adatlapok visszakereshetők az adatbázis összetett keresőjével (http://lldb.elte.hu/admin/search_2.php) az alább ismeretetett megszorítások és beállítások figyelembevételével.

13 A vizsgálatból ennek megfelelően kizártuk a datálatlan adatlapokat és azokat is, amelyek nem voltak beilleszthetők ebbe a kétosztatú korszakolásba, így pl. a 201-400-ra datálható adatlapokat. 
1. táblázat. A mássalhangzói hibák viszonylagos gyakorisága az LLDB alapján

LLDB teljes gyưjtési terūlete alapján, Kr. u. 1-300 ( $\mathrm{N}=5664)$

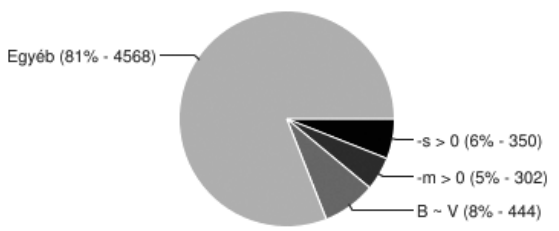

a. Korai korszak (I-III. sz.)
LLDB teljes gyüjtési terūlete alapján, Kr. u. $301-700(\mathrm{~N}=4072)$

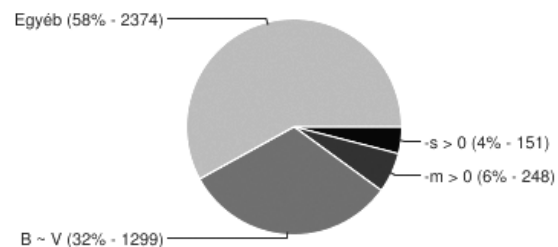

b. Késői korszak (IV-VII. sz.)

tisztán hangtani hátterü feliratos hibáinak megoszlási szerkezetét, ${ }^{14}$ de csak a vizsgálat szempontjából fontos - Herman által is vizsgált és figyelembe vett - jelenségekre, a szóvégi - $m$ és $-s$ leesésére, valamint a $B / V$-keverésre korlátozva a megoszlási vizsgálatot, a többi, itt nem fontos jelenséget pedig az 'egyéb' kategóriába egyesítve, sorolva. ${ }^{15}$

Ahogy fentebb láthattuk, Herman szerint a szóvégi $s$-leesések jóval ritkábbak voltak, mint az egyértelműen fonetikai hátterü $B / V$-keverések vagy a szóvégi $m$-leesések. A $B / V$-keverések tekintetében ezt az állítást legalábbis részben, a kései korszak tekintetében, igazolhatjuk is, hiszen arányuk ekkor jóval meghaladja a szóvégi $s$-leesések részesedését: az 1. táblázat $b$. diagramja szerint $32 \% B / V$-keverés $(B \sim V)$ áll szemben $4 \%$ $s$-leeséssel $(-s>0)$. Az is igaz ugyanakkor, hogy a korai korszakban a $B / V$-keverések aránya csak kevéssel múlja felül a szóvégi $s$-leesések arányszámát: az 1. táblázat a. diag-

14 Ennek megfelelően kirekesztettük a vizsgálatból az olyan eseteket, mint FILIVS COMITI = filius comitis (LLDB-14237) vagy OB PIETATE = ob pietatem (LLDB-7380), amelyek nemcsak hangtanilag a szóvégi $-s$ (az adatbázisban kódja $-s>\emptyset$ ) vagy $-m$ (kódja $-m>\varnothing$ ) leesésével, hanem morfoszintaktikailag a dativus és genitivus (kódja dat. pro gen.) vagy az ablativus és accusativus (kódja abl. pro acc.) keverésével is magyarázhatók. Ily módon tisztán hangtani hátterű jelenségek kerültek be az elemzésbe, mint a CVIV IN = cuius in (LLDB-27346, kódja $-s>\emptyset$ ) vagy ANNORV = annorum (LLDB-39689, kódja $-m>\emptyset$ ), ahol párhuzamos, morfoszintaktikai magyarázat nem lehetséges; bekerültek az elemzésbe a szóvégi $-s$ metrikailag igazolható nem ejtésének példái is, mint pl. CVIVS SINT = cuiu' sint hexameterben (kódja elisio -s, LLDB-35308), ahol a szóvégi -s felszíni megjelenése ellenére a metrikai elemzés igazolja a szóvégi mássalhangzó elízióját, azaz kiesését, nem ejtését. A tisztán hangtani hátterű esetek közé soroltuk a nominativusi -us végződésben kieső $-s$ példáit is, mint pl. IVLIANV VET = Iulianus veteranus (LLDB-14892, kódja $-s>\varnothing)$, amelynek az alternatív kódja amúgy acc. pro nom. lenne a Herman-féle morfoszintaktikai magyarázat fényében.

15 Kirekesztettük a vizsgálatból a morfoszintaktikai (tehát a 'Nominalia' vagy 'Verbalia' vagy 'Syntactica etc.' listákról választott) alternatív kóddal rendelkező lapokat, de ugyanígy a 'Vocalismus' alternatív kódúakat is (pl. VIXIT| ANNV VNV = vixit annum unum / anno uno, kódja $-m>\emptyset$, alternatív kódja o: > V, LLDB-52328), és nem vettük figyelembe a pusztán helyesírási hátterű adatokat ( $\mathrm{x}$ > SX / CS / XS / XSS / XX, qu $>\mathrm{CV}, \mathrm{i}(=[\mathrm{j}:] /[\mathrm{j}])>\mathrm{II}, \mathrm{c}>\mathrm{K}, \mathrm{k}>\mathrm{C}, \mathrm{g}>\mathrm{C}$ kódú lapokat) és a $H$ téves írására vagy nem írására vonatkozó kódokat $(\mathrm{H}>0$, aspiratio vitiosa, $\mathrm{ch}>\mathrm{C}$, $\mathrm{ph}>\mathrm{P}, \mathrm{th}>\mathrm{T}, \mathrm{ch}>\mathrm{H}, \mathrm{h}>\mathrm{CH})$ sem, mert a $h$ már a köztársaságkor végére eltűnt a latin hangrendszerből, és írása vagy nem írása pusztán helyesírási kérdéssé vált. Végül kirekesztettük a kontextuálisan vagy filológiai-technikai okokból opcionálisan helyesnek is tekinthető eseteket, amelyek az adatbázisban fortasse recte megjelölésűek. 
ramja szerint ekkoriban csak $8 \% B / V$-keverés $(B \sim V)$ rögzíthető $6 \% s$-leesés $(-s>0)$ mellett. A szóvégi $m$-leesések esetén azonban egyáltalán nem állítható, hogy gyakoribbak vagy sokkal gyakoribbak lettek volna, mint a szóvégi $s$-leesések, hiszen gyakoriságuk mindkét korszakban azonos nagyságrendűnek, hasonló mértékűnek mondható: a korai korszakban ráadásul a szóvégi $s$-leesés kissé gyakoribb is, mint a szóvégi $m$-leesés, ahogy ezt az 1. táblázat a. diagramja mutatja: $6 \%-s>0$ vs. $5 \%-m>0$; a kései korszakban azonban a szóvégi $m$-leesés aránya múlja felül kevéssel a szóvégi $s$-leesést, vö. 1 . táblá$z a t b$. diagramját: $4 \%-s>0$ vs. $6 \%-m>0$. Mindenesetre ezek az azonos nagyságrendü arányszámok a két szóvégi mássalhangzó leesései tekintetében éles ellentétben állnak a Herman által közölt arányokkal, miszerint a szóvégi $m$ leesése tizenötször vagy húszszor gyakoribb, mint a szóvégi $s$ leesése! ${ }^{16}$ Ekkora különbség nyilván nem magyarázható mérési hibával, csak módszertani különbségekkel a mérési kritériumok tekintetében, közelebbről abban, hogy az $m$-leesések számos esete közül melyeket tekintjük pusztán fonetikai hátterünek és melyeket morfoszintaktikailag is értelmezhetőnek.

Herman ugyanis kontrasztív adatait elsősorban Väänänennek a pompeji falfeliratok latin nyelvét feldolgozó, 1966-ban publikált munkájából merítette:17 „Pompejiben Väänänen $(1966,80) 23$ példát talált a »nyilvánvaló ok nélküli szóvégi $s$-kiesés « esetére, ellenben körülbelül 170 példát a »nyilvánvaló ok nélküli szóvégi $m$-kiesés« esetére (lásd ugyanott 73-75)”. ${ }^{18}$ A „nyilvánvaló ok nélküli” kiesés Väänänennél azt jelenti, hogy az érintett mássalhangzó nem technikai okokból hiányzik (pl. helyszűke, rövidítés etc. miatt), továbbá hiánya nem magyarázható mondattani, morfoszintaktikai ingadozásokkal, változásokkal sem: ezeket ugyanis Väänänen az $m$ esetében az a) pontban tárgyalja a 72-73. oldalon („Cas d'omission de $-m$ admettant une explication non phonétique”), ebből következően a b) pontban tárgyalt „nyilvánvaló ok nélküli szóvégi $m$-kiesések” a fonetikai hátterü hiányokra vonatkoznak. Väänänen ugyanígy jár el a szóvégi $s$-kieséseknél is, 79. o.: „a) Omissions non phonétiques de -s” és 80. o.: „b) $s$ final omis sans raison apparente."

Väänänennek a „nyilvánvaló ok nélküli szóvégi $m$-kiesés” jelenségére hozott példái azonban nagyrészt olyan esetekre vonatkoznak, amelyeknél az accusativus - $m$ végződése hiányzik: pl. $-a(m)$ végű accusativusok („Accusatifs en $-a(m)$ ”, 73-74. o.), mint Succesus amat ancilla (m) ('Sussesus szereti a szolgálólányt') és ad porta(m) Romana(m) ('a római kapunál') vagy $-e(m)$ végű accusativusok („Accusatifs en -e(m)”, 74-75. o.), mint qu(a)e amas Felicione (m) ('aki szereted Feliciót') és ante aede(m) ('ház előtt') stb. Ezeknél azonban az - $m$ hiánya nemcsak fonetikai, hanem morfoszintaktikai változásokkal, esetkeveréssel is magyarázható. Így az ilyen jelenségek az adatbázisunkban alternatív kódolást kapnak: az „- $a$ végű accusativusok” nom./abl. pro acc. (= accusativus helyett

16 Herman: i. m. (4. jegyz.) 35.

17 V. Väänänen: Le latin vulgaire des inscriptions pompéiennes. Berlin 1966.

18 Herman: i. m. (4. jegyz.) 35, 3. jegyz.: „A Pompéi, Väänänen $(1966,80)$ a relevé 23 exemples de »s final omis sans raison apparente«, qui s'opposent à environ 170 cas de $» m$ omis sans raison apparente« (ibid. 73-75)." 
nominativus vagy ablativus használata), az „-e(m) végű accusativusok” pedig abl. pro acc. (= accusativus helyett ablativus) kódot, és éppen ezért ezek az esetek nem képezhetik egy tisztán fonetikai elemzés tárgyát. A Hermantól átvett Väänänen-féle és a mi gyakorisági mérésünk eredménye közötti jelentős különbségnek tehát ez áll a hátterében.

Felmerül a kérdés, hogy mennyire jogos ezeknek az eseteknek a kizárása egy tisztán fonetikai elemzésből. Álláspontunk szerint teljesen indokolt, mert ezeknél a jelenségeknél nem lehet figyelmen kívül hagyni a morfoszintaktikai magyarázat lehetőségét. A vulgáris latinban ugyanis az accusativus és az ablativus egybeolvadása teljesen általános jelenség volt, ${ }^{19}$ ami minden fönévragozási csoportra, deklinációra kiterjedt, egyes és többes számban is érvényesült, és elöljárószavak, prepozíciók után is jelentkezett, továbbá mondatrövidítő szerkezetekben is, mint amilyen az ablativus absolutus.

Adatbázisunk kiragadott példái e folyamat általánosságát jól jelzik: LLDB-59514: NATVS | CASAS MAIORES = natus Casis Maioribus (acc. pro abl.; 'született Casae Maiores-ban'), LLDB-42799: AB CONSERVAS | PEDISEQVAS = a conservis pedisequis (acc. pro abl.;'a rabszolgatársnőkés komornákáltal' ti.állíttatott a síremlék), LLDB-10836: OB MERITIS = ob merita (dat./abl. pro acc.; 'érdemei miatt'), LLDB-6152: ADIVTANTIBVS NEPO|TES SVOS FILIES FILIOS GREGOR|IO ET LAVRENTIO FRATRES = adiutantibus nepotibus suis, filiae filiis, Gregorio et Laurentio fratribus (ablativus absolutus accusativis permixtus; 'unokái, azaz lányának fiai, a testvérpár Gregorius és Laurentius segítségével' ti. állíttatta valaki a síremlékét) stb. Ennek megfelelően az olyan esetek, mint ARA POSVIT = aram posuit (LLDB-44030, nom./abl. pro acc. / - $m>$ >; 'oltárt állíttatott'), TITVLO PO|S = titulum posuit (LLDB-17619, dat./abl. pro acc. / -um > O; 'síremléket állíttatott') vagy EXTRA | MACERIA = extra maceriam (LLDB-35448, nom./abl. pro acc. / $-m>\emptyset$; 'falon kívül') és [E]XTRA FVNDO = extra fundum (LLDB-50658, dat./abl. pro acc. / -um > O; 'telken kívül') mind komplex, fonológiai és morfoszintaktikai értelmezéssel bírnak, és ezért Väänänen fentebb említett (az adatbázisunkból idézettekkel azonos szerkezetű) példáinál sem lehet a morfoszintaktikai magyarázat lehetőségét kizárni és pusztán az - $m$ ejtésének megszűnésével számolni. Nem lehet kizárni az esetkeverés lehetőségét az OB HONORE = ob honorem (LLDB-44959, abl. pro acc. / - $m>\varnothing$; 'megtiszteltetés miatt') esetén az OB HO|NORIBVS = ob honores (LLDB-58148, dat./abl. pro acc. 'megtiszteltetései miatt') miatt és a CVM | QVAM = cum qua (LDB-41852, acc. pro abl. / -ø > -m; 'akivel' nőnemben) esetében sem a C|] VM QVEM = cum quo (LLDB-48790, acc. pro abl. 'akivel' hímnemben) miatt. Ha a többes számú OB HO|NORIBVS és a C|]VM QVEM esetén a hangtani magyarázat fel sem merül, akkor a morfoszintaktikai magyarázatot az OB HONORE és a CVM | QVAM esetében sem lehet kizárni. ${ }^{20}$

19 Vö. Herman: i. m. (1. jegyz.) 48.

20 Az esetkeverésekhez lásd Adamik B.: A számítógépes latin dialektológia műhelyéből: az esetrendszer átalakulásának területi különbségei a feliratos anyag tükrében In: Hereditas Graeco-Latinitatis I.: Studia moralia. Szerk. Tóth O. Debrecen 2014. 9-31. 
2. táblázat. Az esetkeverések viszonylagos gyakorisága az LLDB alapján

LLDB teljes gyưjtési terūlete alapján, Kr. u. 1-300 ( $\mathrm{N}=1623)$

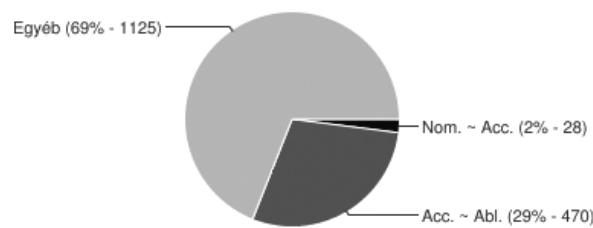

a. Korai korszak (I-III. sz.)
LLDB teljes gyüjtési terūlete alapján, Kr. u. 301-700 ( $\mathrm{N}=976$

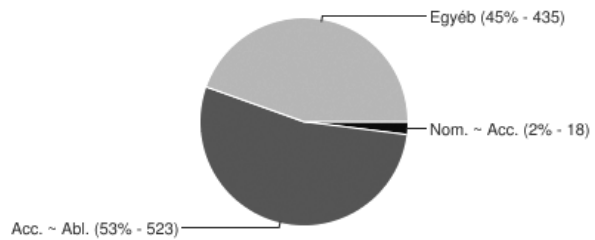

b. Késői korszak (IV-VII. sz.)

Emiatt alakult tehát úgy, hogy adatbázisunk szerint a szóvégi $s$ és $m$ leeséseinek arányszámai azonos nagyságrendűek lettek, amiből az is következik, hogy a szóvégi $m$ leeséseinek magyarázatára evidensnek tartott hangtani értelmezést a szóvégi $s$ hiányainak analízisénél sem lehet kizárni, figyelmen kívül hagyni. Mindez tehát újra megnyitja az utat a hangtani magyarázat előtt, amely még valószínűbbnek látszik, ha megtekintjük a nominativus és accusativus közti keverések arányszámait a 2. táblázat diagramjain. ${ }^{21}$

Az esetrendszer változásainak főbb tendenciáival azért kell itt röviden foglalkoznunk, mert Herman itt tárgyalt értelmezése is egy ilyen jelenség, az accusativusnak a nominativusra történő funkcionális kiterjedésének feltételezésén alapult. Mint fentebb utaltunk rá, Herman szerint az afrikai latinságban az - $u(s)$ nominativusok összekeverhetővé és felcserélhetővé váltak az $-u(m)$ accusativusokkal, legalábbis a nominativus funkcióiban (vö. Latrone, Vagulu cadant < Latro, Vagulus cadant "Latronem Vagulum cadant). Ez az afrikai átoktáblák szövegtípusára amúgy releváns magyarázat azonban láthatólag nem müködik más típusú, afrikai latin feliratos szövegek (pl. kőfeliratok) esetében, és a birodalom többi területének feliratos anyagán sem tünik müködőképesnek, beleértve az átoktáblákat is. Amint arra ugyanis már fentebb is utaltunk, a nominativus és accusativus közötti keverések rendkívül ritkák a vizsgált anyagban, különösen, ha az accusativus és ablativus közötti keverések jelentős gyakoriságához mérjük őket. A 2. táblázat diagramjai beszédesek e tekintetben, hiszen a nominativus és accusativus közötti keverések arányszáma mindkét korszakban 2\%, míg az accusativus és ablativus közötti keverések arányszáma már a korai korszakban is magas, 29\%, amely még magasabbra, 53\%-ra emelkedik a kései korszakban: ez jól mutatja az utóbbi jelenség növekvő produktivitását és az előbbi stagnáló terméketlenségét a vizsgált korszakokban.

21 A korai korszak $a$. diagramja 28 Nom. Acc. (= 13 nom. pro acc. +15 acc. pro nom.) és 470 Acc. $\mathrm{Abl}$ (= 169 acc. pro abl. +70 nom./acc. pro abl. + 102 dat./abl. pro acc. +129 abl. pro acc.) típusú adatot ábrázol. A kései korszak $b$. diagramja 18 Nom. Acc. (= 8 nom. pro acc. +10 acc. pro nom.) és 523 Acc. $\sim$ Abl (= 190 acc. pro abl. +87 nom./acc. pro abl. + 116 dat./abl. pro acc. +130 abl. pro acc.) típusú adatot jelenít meg. Más típusú, jelen vizsgálat szempontjából másodlagos esetkeverések (pl. dat. pro gen., gen. pro dat. stb.) az 'Egyéb' kategóriába lettek sorolva, és egyesítve vannak ábrázolva. 
4. Mindez végül is felveti annak a lehetőségét, hogy az afrikai átoktáblákon található nominativus helyetti accusativusok értelmezésére is nagy valószínűséggel más magyarázatot kell keresnünk. A legvalószínűbb alternatív értelmezést egyébként maga Herman javasolta, ${ }^{22}$ csak éppen kevésbé tartotta azt valószínűnek, tudniillik, hogy ezeket az eseteket az ún. lista- vagy listázási (felsorolási) accusativus jelenségével is meg lehet magyarázni. Adams ezt a magyarázatot már előbbre valónak ítélte, mint azt a magyarázatot, amely mellett Herman végül döntött (és amelyről Adams úgy nyilatkozott, hogy „lehet benne valami”). Adams szerint ugyanis az érintett hadrumetumi átoktáblák, amelyek kocsihajtók és versenylovak hosszú névlistáit tartalmazzák olyan igék kíséretében, mint cadat vagy cadant ('bukjon fel', 'bukjanak fel') - sokszor az egyeztetés szabályait felrúgva többes számú alany mellett egyes számú állítmányt használnak, és fordítva, mint pl. Ganimede Cursore cadat ('Ganimedes, Cursor, bukjon fel') vagy Delusore cadant ('Delusor, bukjanak fel') -, sajátos, egyfajta korlátozott szintaxissal bírnak. ${ }^{23}$ Szövegkompozíciójuk emlékeztet egy másfajta szövegtípus hasonló jellegzetességekkel bíró listáira, mégpedig Apicius receptjeire, amelyekben a hozzávalók felsorolásánál az egyes tételek hol nominativusban, hol accusativusban állnak. ${ }^{24}$

Ilyesfajta szövegre jó példa az Audollent által kiadott hadrumetumi, II-III. századi átoktábla, amelyet Kropp is kiadott, és az EDCS is közölt: ${ }^{25}$ ez utóbbi minden érintett alakot nominativusként állít helyre, kiegészítve a „hiányzó” szóvégi $s$-eket mint pl. $\mathrm{Va}$ gulu(s), illetve kirekesztve a „fölösleges” szótagokat, mint Latro\{ne\}. ${ }^{26}$ Herman azonban, ahogyan erre Adams is felhívta a figyelmet, ${ }^{27}$ helyesen tekintette ezeket az alakokat $-m$ nélküli accusativusoknak, hiszen az - $u$ végű alakok melletti 3. deklinációs formák sem lehetnek mások, mint $m$ nélküli accusativusok. A példaszöveg tehát, ha nem is helyesen, de a nyelvi valóságnak megfelelően így hangzik: Latrone $(m)$ Vagulu(m) cadant és nem Latro\{ne\} Vagulu(s) cadant („Latro, Vagulus, bukjanak fel”).

Az Adams-féle magyarázat helyességét egy további érvvel is megtámogathatjuk, ha egybevetjük a most tárgyalt átoktábla megszövegezési sajátosságait az Audollent-től közölt reprodukció, illetve kiadás segítségével.

22 Herman: i. m. (4. jegyz.) 39.

23 Vö. Adams: i. m. (9. jegyz.) 250.

24 Vö. Apicius 9, 10, 3: ius in sarda: ... mentam, cepam ... ('Bonitóhoz való mártás: ... mentát, hagymát ...) és 9, 10, 6: ius in mugile salso: ... cepa, menta ... ('Mártás sült tonhalivadékhoz: ... hagyma, menta...') idézi Adams: i. m. (9. jegyz.) 229 (a mártásnevek fordításai innen származnak: M. G. Apicius: Szakácskönyv a római korból. Budapest 1996. 169.). Ezt a jelenséget nevezte „Rezeptakkusativ”-nak Svennung (vö. J. Svennung: Untersuchungen zu Palladius und zur lateinischen Fach- und Volkssprache. Lund 1935. 186), vö. még J. Hofmann - A. Szantyr: Lateinische Syntax und Stilistik. München $1972^{2}$. 29-31; hasonló listákhoz vö. Väänänen: i. m. (17. jegyz.) 117.

${ }^{25}$ A. Audollent: Defixionum tabellae quotquot innotuerunt tam in Graecis Orientis quam in totius Occidentis partibus. Luteciae Parisiorum 1904. n. 275; A. Kropp: Defixiones. Ein aktuelles Corpus lateinischer Fluchtafeln. Speyer 2008. n. 11.2.1/12. EDCS = Epigraphik-Datenbank Clauss / Slaby (http://db.edcs. eu/epigr/).

26 A teljes szöveget lásd az EDCS-ben az EDCS-34000306 azonosító alatt.

27 Adams: i. m. (9. jegyz.) 249. 


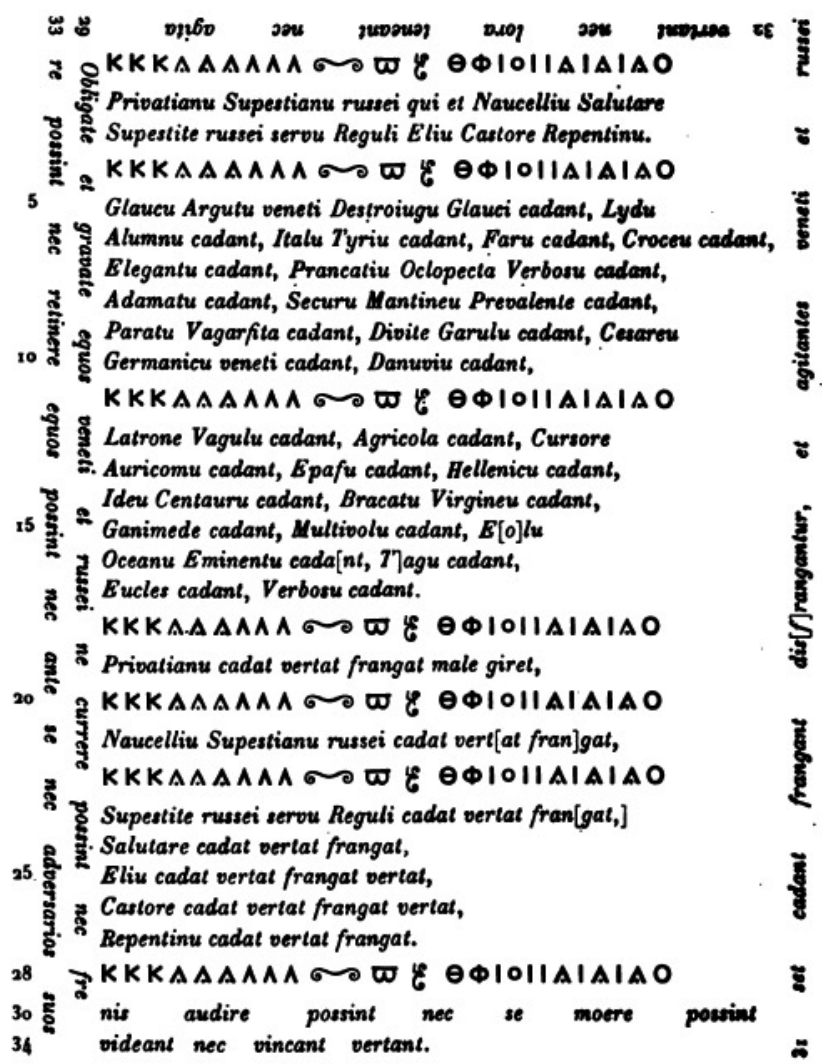

Az átoktábla központi része tartalmazza az elátkozott nevek listáit és az átok vonatkozó igéit, míg a központi rész köré írt szöveg tartalmazza az átok teljes, kifejtett szövegét, amely az alvilági istenségeket erre kéri: Obligate et gravate equos ... et agitantes ... („Kössétek meg és nehezítsétek el lovaikat ... és hajtóikat ...”) stb. ${ }^{28}$ Feltűnő, hogy ebben a szövegrészben nem találunk esetkeverést, sem szóvégi $s$-hiányt. Ez a körülmény is érv lehet amellett, hogy a központi részben szereplő névlisták - $u$ végű alakjai nem az $-s$, hanem az - $m$ leesésével jöhettek létre, tehát valójában accusativusok szerepelnek itt, és nem nominativusok, ahogy erre a Latrone (m)-típusú alakok is utalnak. Szembeötlö, hogy ebben a névlistákat tartalmazó részben egyetlen egyértelmű nominativus található, és az hozza a szóvégi $s$-t: Eucles cada\{n\}t („Eucles, bukjanak fel”). 
3. táblázat. Az esetkeverések viszonylagos gyakorisága Afrikában az LLDB alapján

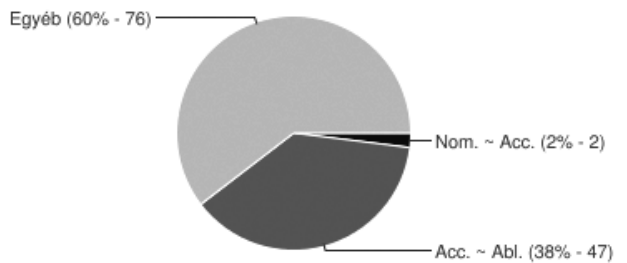

a. Korai korszak (I-III. sz.)

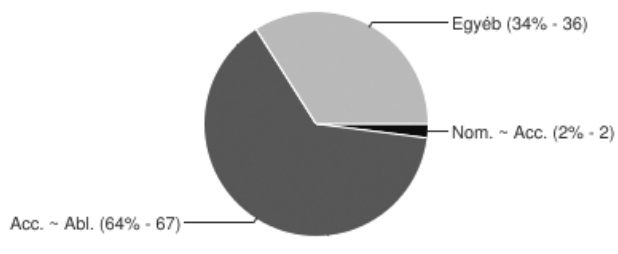

b. Késői korszak (IV-VII. sz.)

Végül a listázási, felsorolási accusativusra építő értelmezés mellett és az accusativus és nominativus közti keverésre építő magyarázat ellen szól a nominativus és accusativus közötti keverések nagyon alacsony, 2\%-os aránya az afrikai (nem átoktábla-típusú) feliratokon, amely éles kontrasztban áll az accusativus és ablativus közötti magas, 38\%-os, illetve 64\%-os keverési arányszámokkal (vö. a 3. táblázat diagramjait). ${ }^{29}$

5. Az eddigiek fényében rátérhetünk a hangtani alapú magyarázatra. Ahogy már fentebb is említettük, a pusztán hangtani hátterü $s$-leeséseket e vizsgálat során nemcsak területi és időbeli megoszlásuk, hanem hangtani környezetük tekintetében is elemzés tárgyává tesszük. Ezt az teszi lehetővé, hogy az adatbázisban a szóvégi $s$-hiányoknál nemcsak az érintett, hanem a rákövetkező szót is megadjuk.

Az adatbázisban emellett azt is jelezzük, ha az $s$-leesés sor végén következett be: az ilyen eseteket álló vonallal (|) jelöljük, és elkülönítve (de nem kirekesztve) szerepelnek az elemzésben is. Ezt az elkülönítést igazából arra a szakirodalmi álláspontra tekintettel tettük meg, amelyet pl. Adams is képvisel: ${ }^{30}$ eszerint a sorvégi $s$-leesések egyfajta, a sorvégi helyhiány okozta rövidítéseknek tekintendők, így egy nyelvészeti elemzésnél figyelmen kívül hagyandók, minthogy létrejöttüket alapvetően nyelven kívüli, technikai okokkal kell magyarázni. A sorvég okozta helyhiány által kiváltott rövidítési kényszer létezésében azonban több okból is kételkedhetünk, többek között azért, mert az ilyen helyzetek kezelésére a római feliratkészítés gyakorlatában több megoldás is létezett. ${ }^{31}$

29 A korai korszak $a$. diagramja 2 Nom. $\sim$ Acc. (= 1 nom. pro acc. +1 acc. pro nom.) és 47 Acc. $\sim$ Abl (= 12 acc. pro abl. +17 nom./acc. pro abl. +8 dat./abl. pro acc. +10 abl. pro acc.) típusú adatot ábrázol. A kései korszak $b$. diagramja 1 Nom. $\sim$ Acc. (= 1 nom. pro acc. +1 acc. pro nom.) és 67 Acc. $\sim$ Abl (= 3 acc. pro abl. + 48 nom./acc. pro abl. +5 dat./abl. pro acc. +11 abl. pro acc.) típusú adatot jelenít meg. Más típusú, jelen vizsgálat szempontjából másodlagos esetkeverések (pl. dat. pro gen., gen. pro dat. stb.) itt is az 'Egyéb’ kategóriába lettek sorolva, és egyesítve vannak ábrázolva.

30 Adams: i. m. (9. jegyz.) 33.

31 Ezekhez általában vö. J. Edmondson: Inscribing Roman Texts: Officinae, Layout, and Carving Techniques. In: The Oxford Handbook of Roman Epigraphy. Eds. Ch. Bruun - J. Edmondson. Oxford 2015. $125-126$. 
Az egyik ilyen a ligatúrák, betűkötések alkalmazása volt, amellyel helyet lehetett megtakarítani (epigráfiai jele: - az érintett betűk felett). Használatuk elsősorban a koracsászárkori, pogány korszakra jellemző, de a kései, keresztény korszakban is akad példa rájuk. Különféle sorvégi $V S$-ligatúrákat figyelhetünk meg harmadik századi pannoniai feliratokon, pl. RIU 2, 540: Caeciliūs|, RIU 3, 879: Maximūs|, a keresztény korszakból pedig idézhetünk egy IV. századi itáliai feliratot (CIL 11, 1728): Constantiv̄, ahol az -u fölötti jel egyfajta fektetett $s$-ként értelmezhető (és így egy speciális ligatúráról vagy legalábbis betűkapcsolatról beszélhetünk). ${ }^{32} \mathrm{~A}$ másik, a sor végén helytakarékosságot lehetővé tévő eljárás kis méretű kapitális betűk alkalmazása volt nagy méretű kapitális betűk között vagy felett, pl. a pannoniai, II-III. századi RIU 3, 681: Q\{a\}vartus| esetén egy kis $v$ került a $T$ és $S$ közé, a szintén II-III. századi RIU 1, 100: Primus| esetén pedig egy $s$ az $V$ fölé. A két eljárást egyszerre alkalmazza egy római felirat, a CIL 6, 20167 első két sora: Iulius $\mid$ Orphe $\widehat{u s} \mid$, ahol az első sorban egy kis $s$ van a sor végén a $V$ mögött, míg a második sor végén egy VS-ligatúra oldja meg a helyhiányt. A harmadik megoldás az volt, hogy ha kifutott a vésnök a helyből, egyszerüen a feliratmezőn kívül, a keretre véste fel a hátralévő betüt, ahogy ez pl. a következő, pannoniai feliratokon történt: a 3. századi RIU 3, 720: Avitianu|s| és Secundu|s| vagy az I-II. századi RIU 1, 182: Calaviu|s| és vetera$n u|s| .^{33}$ Következésképpen megvolt a módja annak, hogy egy szóvégi $s$-t megjelenítsenek a sor végén a helyhiány ellenére is, amennyiben erre megvolt a szándék és a motiváció, azaz egy ilyen mássalhangzó írását fontosnak ítélték: így helyhiány okozta betűelhagyási kényszerről aligha beszélhetünk. A sorvégi betűelhagyási kényszernek tulajdonított $s$-elhagyások között ráadásul olyan eseteket is kirekeszt(het)tek, amelyeknél az $s$-leesés ugyan valóban sor végén áll, de utána lett volna még több-kevesebb hely felvésésére: pl. AE 1956, 51: Floru(s) || (LLDB-20482), CIL 13, 816: eiu(s) || (LLDB-21814), AIJ 29: Serenu(s) | (LLDB-2113), TitAq 1, 299: Fe stu(s)| (LLDB-19309) stb. (ezeket az eseteket betűköz jelzi a | jel vagy az egész felirat végét jelző || jelek előtt az adatbázisban).

Végül egy nyelvészeti jellegű megfigyelés is az ellen szól, hogy egy ilyen általánosan érvényesülő, a helyhiánytól motivált betűelhagyási kényszert tételezzünk fel, fogadjunk el a sor végén. A sardiniai latin feliratok tele vannak a mássalhangzórendszer változásait érintő hibákkal (ezek legnagyobb, $60 \%$-os részét a $b$ és $v$ fúziójáróra utaló $B / V$-betűcserék teszik ki, 209 esetből 123), ugyanakkor a szóvégi $s$ leesésére alig vannak példáink

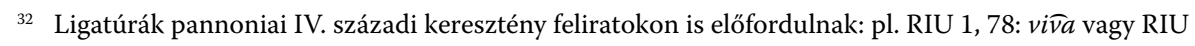
1, 82: ̄patre.

33 És akkor a legegyszerűbb megoldást, hogy a vésnök ilyen helyzetben a következő sor elejére véste a szóvégi $s$-t, amely számára már nem volt hely az adott sorban, még nem is említettük, pl. RIU 4, 995: Ursu|s, ehhez a jelenséghez vö. C. Proskauer: Das auslautende -s auf den lateinischen Inschriften. Straßburg 1910. 52, aki egyébként szintén ismerteti a most tárgyalt praktikákat, de ennek ellenére kirekeszti az összes ilyen esetet a nyelvészeti példák közül, valószínűleg a korabeli hiperkritika szelleme előtt meghajolva. 
(209 adatból 3 vagy 4, azaz 2\%-nyi esetben), ${ }^{34}$ holott a sardiniai feliratok hemzsegnek a sor végére írt szóvégi $s$-ektől mind a korai, pogány és kései, keresztény korban! ${ }^{35}$ Ehhez képest egyetlenegy esetben, a II-III. századi CIL 10, 7973-es feliratán figyelhetjük csak meg, hogy sor végén $s$-leesés történt: Amarantu(s) | pater (LLDB-65061). Hogy fordulhatott az elő, hogy egy ilyen, általánosnak vélelmezett jelenség Sardiniában egyetlen kivételtől eltekintve egyáltalán nem jelentkezett? Csak úgy, hogy a sorvég okozta helyhiány által kiváltott rövidítési kényszer nem volt általános érvényü, és esetleg nem is létezett, vagy ha alkalmanként jelentkezhetett is, nem lehet neki olyan általános érvényü hatást tulajdonítani, mint ahogy a szakirodalom ezt teszi. Következésképpen megalapozatlan kirekeszteni a szóvégi $s$-leesések közül a sorvégi eseteket, így ennek megfelelően mi mindvégig figyelembe fogjuk venni előfordulásaikat az $s$-leesések össz-számai között, ugyanakkor számukat elkülönítve mindig megadjuk a vonatkozó diagramokhoz tartozó lábjegyzetekben.

A fentiek tükrében tehát az $s$-leeséseket hangtani környezetük szerint három csoportba osztottuk.

1. Rákövetkező mássalhangzó előtti s-leesések (pl. EIV MATO = eius Mato, LLDB-4518). ${ }^{36}$

2. Rákövetkező magánhangzó előtti $s$-leesések (pl. CVIV IN = cuius in, LLDB-27346).

3. Olyan $s$-leesések, ahol a hangtani környezet meghatározása különböző okokból nem lehetséges; ezeket értelemszerüen kihagyjuk a fonoszintaktikai elemzésből. ${ }^{37}$

34 LLDB-64270: $-s>\emptyset$, DIEBV XVII (II.--III. sz.), LLDB-64271: -s > ø, ANNO XV (V. sz.; alternatív kódja abbreviatio insolita, ti. az annorum rövidítése is lehet, kontextus hiányában nem eldönthető), LLDB-64272: -s > ø, A]NNO PL M (V. sz.; vixit állhatott előtte, ti. a megelőző, ránk maradt qui erre utal), LLDB-64273: -s > ø, PLV MINVS (6. sz.); ezekhez 1. G. Lupinu: Latino epigrafico della Sardegna. Aspetti fonetici. Nuoro 2000, 65

35 Az EDCS adatai alapján (2017. 11. 01-i állapot szerint) a 378 darab, I-III. századra datálható itteni feliraton 164 alkalommal, a 288 keresztény kori sardiniai feliraton pedig 82 alkalommal figyelhetünk meg kiírt szóvégi $s$-t a sor végén.

36 Ebben az első csoportban egy további megkülönböztetést is tettünk aszerint, hogy az $s$-leesés rákövetkező $s$ - előtt következett-e be, vagy sem. Ilyenkor ugyanis egyfajta haplológiával, egyszerűsítő írásmóddal is számolhatunk. Kizárni azonban ezeket az eseteket sem tudjuk a vizsgálatból, mert a metrikus, pl. hexameteres feliratok ilyen helyzetben bekövetkező -s elíziói (adatbázisbeli kódjuk 'elisio - $s$ ') arra utalnak, hogy a szóvégi -s hangot ilyen helyzetben (ahogy egyéb mássalhangzók előtt) sem ejtették: GENVS [S]I = genu' si LLDB-29412, SITVS SVM = situ' sum LLDB-51840, LVTVS SI = lutu' si LLDB-55063, ZENONIS SVASIT = Zenoni' suasit LLDB-60455, DEDITAS SIBI = dedita' sibi LLDB-63623; e problémához részletesebben vö. B. Adamik: Zur Prosodie, Metrik und Interpretation von Catulls Carmen 116. Wiener Studien 127 (2014) 154.

37 Ilyenek pl. ha a leesés az egész felirat végén következett be - az adatbázisban ezeket jelöljük dupla álló vonallal: ||, pl. EIV||, LLDB-21814 -, vagy kitörés előtt - jele az adatbázisban a szögletes zárójel: [, pl. TRE [, LLDB-48079 -, vagy ha nem lehetett azonosítani a rákövetkező hangot, pl. mert egy töredékes V[ hangértéke $u$ és $v$ is lehet, vagy mert töredékes római szám következett, amelynek megfeleltetése nem egyértelmű, pl. MESE V[, (LLDB-32011) esetén a töredékes V lehet V = quinque vagy kiegészítve VI = sex, VII septem, VIII octo, sőt VIIII = novem . 
A gondolat, hogy a császárkori szóvégi $s$-leeséseknél figyelemmel legyünk a hangtani környezetre, amelyben bekövetkeztek, természetesen nem új, mert az ólatin korszakban bekövetkezett ugyanilyen jelenségekre ezt a módszert már eredményesen alkalmazták. Azt ugyanis már régen megfigyelték, hogy a Kr. e. III-II. századi ólatin feliratokon a szóvégi $s$-t elsősorban rákövetkező mássalhangzó előtt hagyták el gyakran, míg magánhangzó előtt ritkán, és ebből arra következtettek, hogy a szóvégi $s$ fonetikai megvalósulása a környezettől függött: magánhangzó előtt ejtették, mássalhangzó előtt nem. Ezt a környezetfüggő megvalósulást a korabeli metrikai gyakorlat is reflektálta, amennyiben a rövid magánhangzó utáni szóvégi -s gyakran nem alkot pozíciót rákövetkező mássalhangzó előtt, de magánhangzó előtt mindig. ${ }^{38}$ Ezt jól példázza Ennius következő sora (Annales 377): nos sumus Romani, qui füimus ante Rudini (az aláhúzott $s$ nem alkot pozíciót, tehát nem ejtették: sumu'). Az ólatin feliratokon a szóvégi -s leesése azonban, szemben az irodalmi metrikus szövegekkel, nemcsak mássalhangzó előtt, pl. Populicio(s) M(arci) CIL $1^{2}, 28$, hanem magánhangzó előtt is előfordult, pl. castu(s) amabili(s) CIL $1^{2}, 1259$, igaz, viszonylag ritkán vö. a 4. táblázat diagramjait. ${ }^{39}$

A mássalhangzói környezet dominanciája a szóvégi $-s$ kiesésében a magánhangzóival szemben egyértelmüen bizonyítható, nemcsak önmagában véve, a kétféle bekövetkezés arányait összehasonlítva ( $205=90 \%$ vs. $24=10 \%)$, hanem akkor is, ha ezeket az arányszámokat egybevetjük azokkal az arányokkal, amikor az -s nem esik le, hanem írásban jelölik ugyanolyan környezetben (6564=76\% vs. 2119=24\%): a rákövetkező mássalhangzó előtt bekövetkező leesés (90\%) és megtartás (76\%) közötti kontrasztív különbség (14\%) a mássalhangzói környezet fontosságára a leesés bekövetkeztében kellőképpen rávilágít. ${ }^{40}$

Ezt az ólatin jelenséget természetesen már régóta megkísérelték bevonni a császárkori, vulgáris latin $s$-törlés vizsgálatába, hátterének felderítésébe, de ez csak negatív konklúziókhoz vezetett. A szakirodalmi konszenzus szerint a szóvégi -s általános hatókörü, és mindenféle környezetre kiterjedő, a késő köztársaságkori nyelvi standardizá-

38 Vö. Adamik. B.: A latin nyelv története az indoeurópai alapnyelvtől a klasszikus latinig. Budapest 2009. 178-179 és Adams: i. m. (9. jegyz.) 132.

39 Vö. $R$. Wachter: Altlateinische Inschriften. Sprachliche und epigraphische Untersuchungen zu den Dokumenten bis etwa 150 v. Chr. Bern - Frankfurt am Main - New York - Paris 1987. 256, 343, 348, $356,434$. E fakultatív kiesés nem szorítkozott pusztán az - $s$-re, hanem a szóvégi - $m$, $-t$ és $-d$ esetén is jelentkezett, vö. Wachter: i. m. 356 és Adamik: i. m. (38. jegyz.) 177-180. CIL $1^{2}=$ Corpus Inscriptiones Latinarum 1. Eds. Th. Mommsen et al. Berlin 1893-1986.

40 Mivel a császárkori anyagot feldolgozó adatbázisunkban a köztársaságkori feliratokat értelemszerűen nem vesszük figyelembe, a vonatkozó, CIL $1^{2}$-ből származó adatokat az EDCS epigráfiai adatbázisból gyüjtöttük ki. A 4. táblázat a. diagramjának adatszerkezete: $s>0 /$ \#C $205=1 . s>0 / \_$\# $156+2 . s>0 /$ \# $\mid \mathrm{C}$

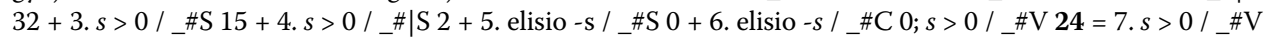
$19+8 . s>0 /$ / \# 5 . A meghatározhatatlan környezetű és éppen ezért a vizsgálatból kizárt esetek száma: 18 $=9 . s>0 / \_$hV $0+10 . s>0 / \_\#|\mathrm{hV} 0+11 .-s>0 / \ldots| \mid 18$ (a || jellel itt összefoglaló jelleggel utalunk azokra az esetekre, ahol a leesés a felirat végén vagy törés előtt következett be). 
4. táblázat. Az $s$-leesés és $s$-megtartás hangtani környezet szerinti megoszlása a CIL 1-ben

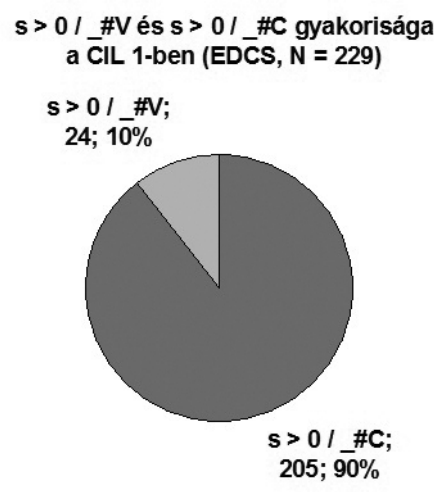

a. $S$-leesés $(-s>0)$
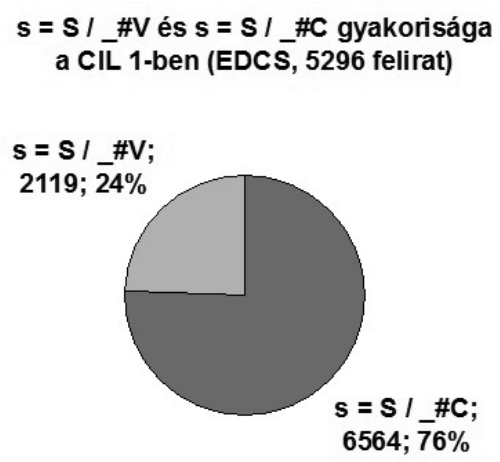

b. $S$-megtartás $(-s=S)$

ciós, normalizációs folyamat ${ }^{41}$ keretében (mind írásban, mind beszédben) bekövetkezett visszaállításának, restaurációjának köszönhetően nincsen kapcsolat az ólatin és a vulgáris latin, illetve újlatin/román jelenség között. Jellemző Adams ítélete: „Volt vajon bármiféle kontinuitás a korábbi, köztársaságkori gyakorlat, amikor a szóvégi $s$-t gyakorta elhagyták itáliai feliratokon, és az újlatin/román viszonyok között, amikor is Itáliában kiveszett az -s? (...) Itt csak egyféle következtetésre lehet jutni a bizonyítékok tükrében. A szóvégi $s$ a társadalom mindegyik rétegének nyelvhasználatában és minden régióban visszaállt a kora császárkorban, és így is maradt évszázadokon keresztül. Az olaszban és más újlatin/román nyelvekben mutatkozó kiveszése nagyon későn következhetett be, és nincsen semmiféle kapcsolata az ólatin korszakbeli helyzettel." ${ }^{2}$ Herman, ahogy fentebb láthattuk, hasonló módon írja le a problémát, de a vulgáris latin és újlatin/román viszonyok közötti összefüggésről jóval óvatosabban, ugyanakkor optimistábban nyilatkozik. $^{43}$

6. Mint fentebb már utaltunk rá, a korai és kései császárkori feliratos anyagban a szóvégi $s$ leesésére viszonylag számos olyan előfordulást találtunk, amelyek létrejöttében nem morfoszintaktikai változások vagy nyelven kívüli, technikai tényezők, hanem

41 Ehhez vö. Adamik: i. m. (38. jegyz.) 196-236 és Adamik B.: Propaganda és a latin nyelv normalizációja. In: Fikció és propaganda az ókorban: Válogatás a VIII. Magyar Ókortudományi Konferencia előadásaiból. Szerk. Mayer P. - Tar I. Szeged 2011. 87-97.

42 Adams: i. m. (9. jegyz.) 135: „Was there any continuity between usage in the earlier Republic, when $-s$ was often left out in inscriptions from Italy, and Romance, where it was lost in Italy? (...) The case can be made that there is only one conclusion fully justified by the evidence. Final $-s$ was restored right across the social spectrum and in all areas by the early Empire, and it was maintained for centuries. The loss that shows up in Italian and some other Romance languages must have occurred very late, and was not a direct continuation of the situation obtaining in the archaic period."

43 Herman: i. m. (1. jegyz.) 39. 
hangtani fejlemények játszottak szerepet. Ezt az adatcsoportot logikusnak tűnt a hangtani környezet szempontjából is megvizsgálni, attól az előfeltevéstől motiválva, hogy a szóvégi $s$ leesésére az eltérő hangtani környezet volt befolyással csakúgy, mint az ólatin korszakban. A következőkben ennek a vizsgálatnak az eredményeit mutatjuk be, először általánosságban, a Római Birodalom teljes latin részének adatain, majd speciálisan, Észak-Itália és Dél-Itália provinciáinak anyagán, mindkét alkalommal a korai és kései korszakra bontást alkalmazva. Ahogy ez az ólatin viszonyok elemzésénél is történt, itt is az $s$-leesés és az $s$-megtartás arányait fogjuk egybevetni aszerint, hogy mássalhangzó vagy magánhangzó áll-e utánuk.

A korai korszak, tehát az I-III. század tekintetében megállapítható, hogy az s-leesések 79\%-a fordult elő rákövetkező mássalhangzó és $21 \%$-a rákövetkező magánhangzó előtt, vö. az 5. táblázat a. diagramját. ${ }^{44}$ Ha megszámoljuk a kiírt szóvégi $s$-ek ugyanezen arányait az EDCS-ben Kr. u. 1-300 közé datált 18716 feliraton, ${ }^{45}$ akkor azt kapjuk, hogy a helyesen kiírt szóvégi $s 73 \%$-ban fordult elő rákövetkező mássalhangzó és 27\%-ban rákövetkező magánhangzó előtt, vö. az 5. táblázat b. diagramját.

A kései korszak, tehát a IV-VII. század tekintetében megállapítható, hogy az $s$-leesések 81\%-a fordult elő rákövetkező mássalhangzó és 19\%-a rákövetkező magánhangzó előtt, vö. a 6. táblázat a. diagramját. ${ }^{46}$ Az EDCS-ben Kr. u. 301-600 közé datált 2624 feliraton ugyanakkor helyesen kiírt szóvégi $s 71 \%$-ban fordult elő rákövetkező mássalhangzó és 29\%-ban rákövetkező magánhangzó előtt, vö. a 6. táblázat b. diagramját.

Mivel a korai korszakban a rákövetkező mássalhangzó előtt bekövetkező $s$-leesés (79\%) és $s$-megtartás (73\%) közötti különbség viszonylag csekély (6\%), nem igazán vagyunk jogosultak feltételezni, hogy az $s$-leesést az eltérő hangtani környezet motiválta volna, hiszen a szóvégi - $s$ átlagos, mássalhangzó előtti gyakoriságát csak kevéssel (10\% alatti különbséggel) múlja felül a szóvégi -s mássalhangzó előtti leesésének gyakorisága. Másrészt viszont a kései korszakban a rákövetkező mássalhangzó előtt bekövetkező $s$-leesés (81\%) és $s$-megtartás (71\%) közötti különbség már szignifikánsnak tekinthető (10\%), így már nagyobb valószínűséggel tételezhetjük fel, hogy az s-leesés egyre inkább függővé vált a hangtani környezettől, azaz egyre gyakoribbá vált rákövetkező mássalhangzó előtt. Ugyanezt a következtetést a korai korszak tekintetében csak óvatosan vonhatjuk le, hiszen ott még pusztán a (kb. 4\% körüli) hibahatárt alig felülmúló (6\%-os) mértékben jelentkezett a mássalhangzói környezet előnye a magánhangzóival szemben. Ugyanakkor mindenképpen figyelemre méltónak tartható az a jelenség, hogy

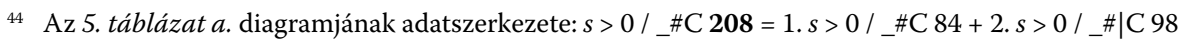

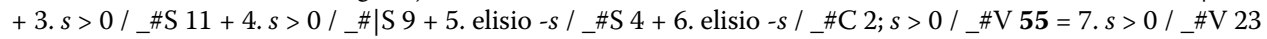
+ 8. $s>0$ /_\#|V 32; A meghatározhatatlan környezetű és éppen ezért a vizsgálatból kizárt esetek száma: $81=$ 9. $s>0$ /_\#hV 5 + 10. $s>0$ /_\#|hV 6+11. -s >0/_\# 70 .

${ }_{45}$ Az EDCS-ből vett adatok a 2017. 09. 01. szerinti állapotot tükrözik.

46 A 6. táblázat a. diagramjának adatszerkezete: $s>0 /$ \#C $106=1 . s>0 /$ \#C $56+2 . s>0 /$ \# $\mid \mathrm{C}$ $23+3 . s>0 / \_$S $15+4 . s>0 / \_\# \mid \mathrm{S} 0+5$. elisio $-s / \_\# \mathrm{~S} 4+6$. elisio $-s / \_$\# $8 ; s>0 / \_\# \mathrm{~V} 25=7 .-s>0 \mathrm{~V} 18+$ 8. $-s>0 \mid$ V 7; A meghatározhatatlan környezetű és éppen ezért a vizsgálatból kizárt esetek száma: $18=9 . s>$ 0 /_\#hV 2+10. s>0/_\#|hV0+11. -s>0/_\#|| 16 . 
5. táblázat. Az $s$-leesés és $s$-megtartás hangtani környezet szerinti megoszlása (I-III. sz.)

\section{s $>0$ I \#V és s > 0 I \#C gyakorisága az \\ LLDB-ben (Kr. u. 1-300, $\mathrm{N}=263$ )}

s > 0 I_\#V;

$55 ; 21 \%$

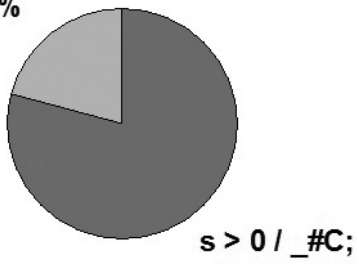

$208 ; \overline{79} \%$

a. S-leesés $(-s>0)$

\section{$\mathbf{s}=\mathbf{S} I$ \#V és $\mathbf{s}=\mathbf{S} I$ \#C gyakorisága az EDCS-ben (Kr. u. 1-300, 18716 felirat)}

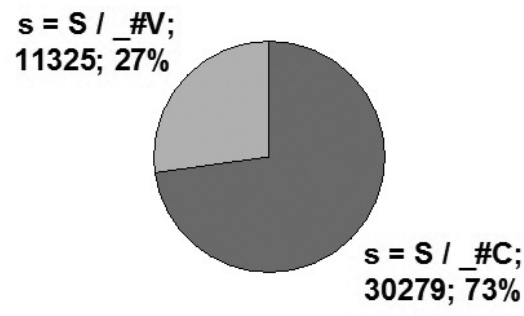

b. $S$-megtartás $(-s=S)$

6. táblázat. Az s-leesés és $s$-megtartás hangtani környezet szerinti megoszlása (IV-VII. sz.)

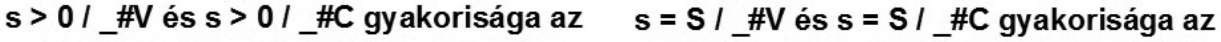 \\ LLDB-ben (Kr. u. $\overline{301-700, N}=131$ ) EDCS-ben (Kr. u. 301-700, 2624 felirat)}

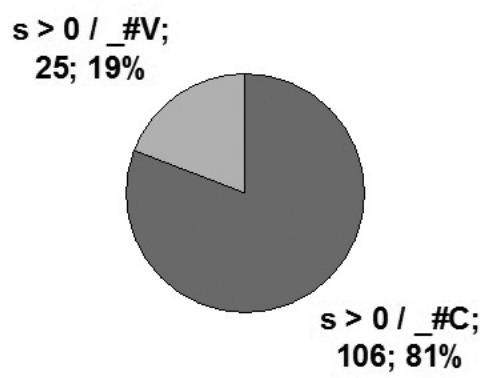

a. S-leesés $(-s>0)$

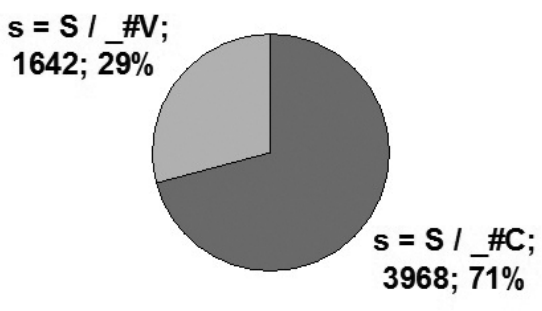

b. $S$-megtartás $(-s=S)$

rákövetkező mássalhangzók előtt az $s$-leesés aránya mindig és mindenhol (a későbbiekben vizsgált területek esetén is) magasabb az $s$-megtartás arányánál: az ellenkezője sosem fordul elö.

7. Ha ugyanezt a vizsgálatot speciálisan, Észak-Itália (Reg. VIII-XI) és (a közép-itáliai provinciákat is magába foglaló) Dél-Itália (Reg. I-VII) provinciáinak anyagán végezzük el, tekintettel az $s$-megtartó „északi” és $s$-elvesztő „déli” olasz dialektusok közötti, fent bemutatott sematikus választóvonalra, amely egybeesik a most tárgyalt két itáliai provinciacsoport közötti határvonallal, akkor a következő eredményeket kapjuk. 
7. táblázat. Az $s$-leesés és $s$-megtartás hangtani környezet szerinti megoszlása Észak-Itáliában (I-III. sz.)

$\mathrm{s}>0$ I \#V és $\mathrm{s}>0 \mathrm{I}$ \#C gyakorisága Észak-Itáliában Reg. VIII-XI (LLLD, Kr. u. 1-300, N = 24)

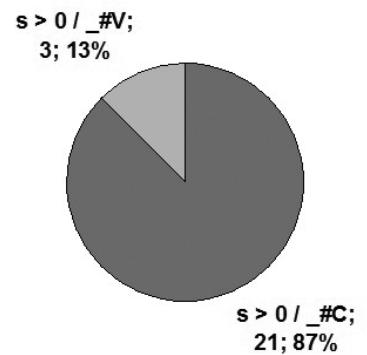

a. $S$-leesés $(-s>0)$ $\mathbf{s}=\mathbf{s} I$ \#V és $\mathbf{s}=\mathbf{S} I$ \#C gyakorisága Észak-Itáliában

Reg. VIII-XI (EDCS, Kr. u. 1-300, 1252 felirat)

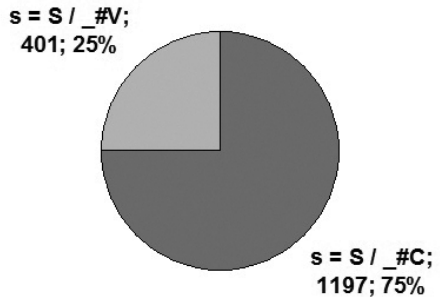

b. $S$-megtartás $(-S=S)$

A hangtani környezetet vizsgálva megállapíthatjuk, hogy a korai korszakban Észak-Itália feliratain a rákövetkező mássalhangzó előtt bekövetkező s-leesés (87\%) és $s$-megtartás (75\%) között szignifikáns különbség (12\%) mutatkozik az $s$-leesés javára. ${ }^{47}$

Ugyanakkor a korai korszakban Dél-Itália feliratain a rákövetkező mássalhangzó előtt bekövetkező $s$-leesés (86\%) és $s$-megtartás (75\%) között az észak-itáliaival majdnem megegyező mértékű, szignifikáns különbség (11\%) mutatkozik az $s$-leesés javára. ${ }^{48}$ Ez azt jelenti, hogy az s-leesés javára az (5. táblázat kapcsán jelzett) összbirodalmi átlagnál (6\%) lényegében kétszer akkora különbség mutatkozik Itália vizsgált két régiójában (Észak-Itália 12\%, Dél-Itália 11\%).

Ha ezek után ugyanezt a vizsgálatot Észak-Itália (Reg. VIII-XI) és Dél-Itália (Reg. I-VII) provinciáinak kései, IV-VII. századi anyagán is elvégezzük, láthatjuk, hogy az $s$-leesés javára mutatkozó különbség csak tovább növekszik, vö. a 9-10. táblázat diagramjait.

A kései korszakban Észak-Itália feliratain ugyanis a rákövetkező mássalhangzó előtt bekövetkező $s$-leesés (95\%) és $s$-megtartás (72\%) között immár 23\%-nyi különbség mutatkozik az $s$-leesés javára. ${ }^{49}$

47 A 7. táblázat a. diagramjának adatszerkezete: $s>0 / \_C 21=1 . s>0 / \_C 1+2 . s>0 / \_\# \mid C 15+$

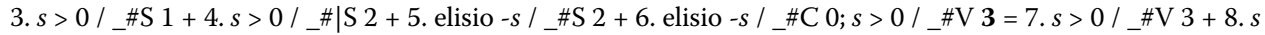
$>0$ / \#|V 0; A meghatározhatatlan környezetű és éppen ezért a vizsgálatból kizárt esetek száma: $1=9 . s>0$ /

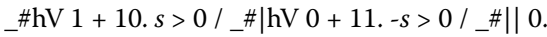

48 A 8. táblázat a. diagramjának adatszerkezete: $s>0 / \_$C $19=1 . s>0 / \_$C $11+2 . s>0 / \_\# C 5+$

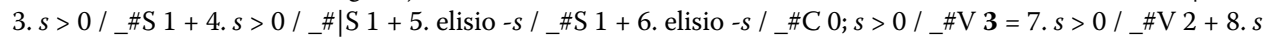
$>0$ /_\#|V 1; A meghatározhatatlan környezetű és éppen ezért a vizsgálatból kizárt esetek száma: $2=9 . s>0$ / _\#hV $0+10 . s>0 / \ldots \#\left|\mathrm{hV} 0+11 .-s>0 / \_\#\right| \mid 2$.

49 A 9. táblázat a. diagramjának adatszerkezete: $s>0 / \_$C $18=1 . \mathrm{s}>0 / \_$C $10+2 . s>0 / \_\# \mathrm{C} 5+$

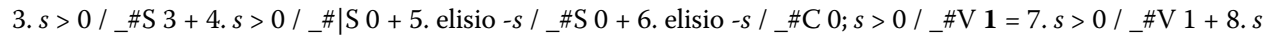
$>0$ /_\#|V 0; A meghatározhatatlan környezetű és éppen ezért a vizsgálatból kizárt esetek száma: $1=9 . s>0$ / _\#hV $0+10 . s>0 /$ \# $\left|\mathrm{hV} 0+11 .-s>0 / \_\#\right| \mid 1$. 
8. táblázat. Az $s$-leesés és $s$-megtartás hangtani környezet szerinti megoszlása Dél-Itáliában (I-III. sz.)

s > 0 I_\#V és s>0 I_\#C gyakorisága Dél-Itáliában

Reg. I-VII (LLDB, Kr. u. 1-300, N = 22)

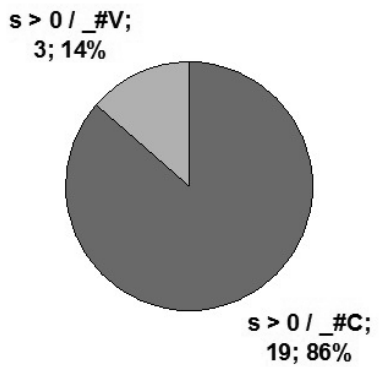

a. $S$-leesés $(-s>0)$
$\mathbf{s}=\mathbf{S} I$ \#V és s = S I_\#C gyakorisága Dél-Itáliában

Reg. I-VII (EDCS, Kr. u. 1-300, 3439 felirat)

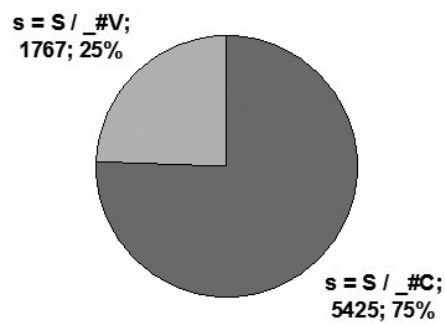

b. $S$-megtartás $(-S=S)$

9. táblázat. Az s-leesés és $s$-megtartás hangtani környezet szerinti megoszlása Észak-Itáliában (IV-VII. sz.)

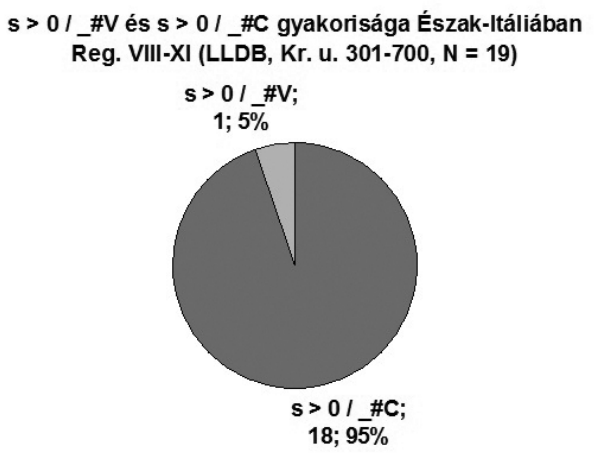

a. $S$-leesés $(-s>0)$
$\mathbf{S}=\mathbf{S} / \# \mathrm{~V}$ és $\mathbf{S}=\mathbf{S} /$ \#C gyakorisága Észak-Itáliában Reg. VIII-XI (EDCS, Kr. u. 301-700, 1681 keresztény felirat)

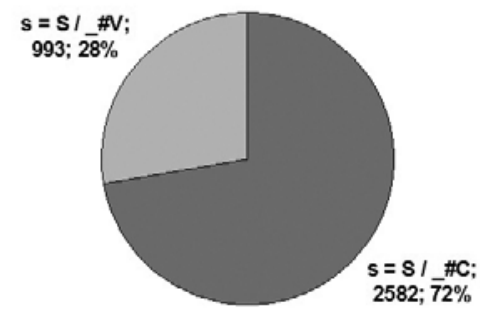

b. $S$-megtartás $(-s=S)$

Ugyanakkor a kései Dél-Itália feliratain a rákövetkező mássalhangzó előtt bekövetkező $s$-leesés (95\%) és $s$-megtartás (75\%) között az észak-itáliait megközelítő, 20\%-nyi különbség mutatkozik az $s$-leesés javára. ${ }^{50} \mathrm{Ez}$ azt jelenti, hogy a kései korszakban az $s$-leesés javára a (6. táblázat kapcsán jelzett) összbirodalmi átlagnál (10\%) ugyanúgy kö-

50 A 10. táblázat a. diagramjának adatszerkezete: $s>0 /$ \# $18=1 . s>0 / \# \mathrm{C} 8+2 . s>0 / \_\# \mathrm{C} 1+$

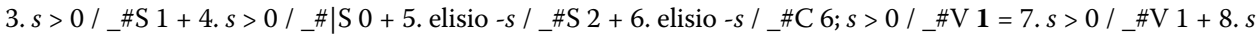
$>0$ /_\#|V 0; A meghatározhatatlan környezetű és éppen ezért a vizsgálatból kizárt esetek száma: $7=9 . s>0$ / _\#hV $0+10 . s>0 /$ \#|hV $0+11 .-s>0 / \_\#|| 7$. 
10. táblázat. Az $s$-leesés és $s$-megtartás hangtani környezet szerinti megoszlása Dél-Itáliában (IV-VII. sz.)

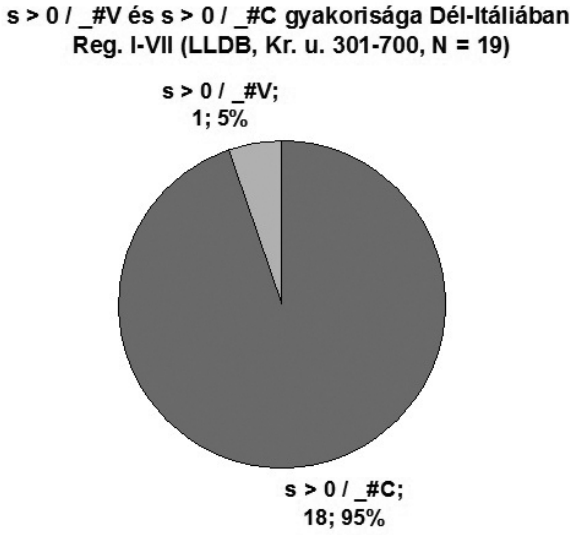

a. $S$-leesés $(-s>0)$
$\mathbf{s}=\mathbf{S} I$ \#V és $\mathbf{s}=\mathbf{S} I$ \#C gyakorisága Dél-Itáliában Reg. I-VII (EDCS, Kr. u. 301-700, 1888 keresztény felirat)

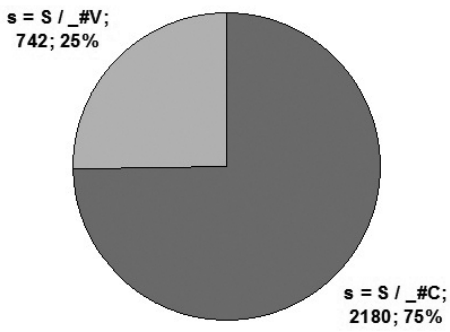

b. $S$-megtartás $(-s=S)$

rülbelül kétszer akkora különbség mutatkozik Itália vizsgált két régiójában (Észak-Itália 23\%, Dél-Itália 20\%), mint a korai korszak esetében.

8. Ha a rákövetkező mássalhangzó előtt bekövetkező $s$-leesés és $s$-megtartás közötti különbség arányainak tekintetében egybevetjük Itália most vizsgált korai és kései császárkori anyagának tanúbizonyságát a köztársaságkori, nagyrészt itáliai feliratokat tartalmazó CIL 1 anyagából levont következtetésekkel, akkor a következőkre jutunk. A köztársaságkori, többnyire ólatin kori (kb. III-II. századi) feliratokon a rákövetkező mássalhangzó előtt bekövetkező $s$-leesés (90\%) és $s$-megtartás (76\%) között az $s$-leesés javára kimutatható kontrasztív különbség (14\%) a mássalhangzói környezet fontosságát a leesés bekövetkeztében kellőképpen igazolja (vö. 4. táblázat). Ebből arra következtethetünk, hogy a szóvégi $s$ hajlamos volt mássalhangzó előtt a kiejtésben elenyészni. Ezt a helyzetet reflektálja az ólatin verselési technika, amelyben az -s gyakran nem alkot pozíciót mássalhangzó előtt, de magánhangzó előtt mindig. A késő köztársaságkorban, úgy a Kr. e. II. század vége felé beinduló standardizációs, normalizációs folyamatoknak köszönhetően, ${ }^{51}$ a szóvégi mássalhangzók mind írásban, mind (művelt) kiejtésben történő helyreállítása, stabilizációja révén a kora császárkorban (vö. 5. táblázat) a rákövetkező mássalhangzó előtt bekövetkező $s$-leesés (79\%) és $s$-megtartás (73\%) között az $s$-leesés javára kimutatható különbség összbirodalmi szinten 6\%-ra csökkent. Észak- és Dél-Itália (Rómán kívüli) területein ez a különbség azonban csak csekély mértékben, 12\%-ra (vö. 7. táblázat), illetve 11\%-ra (vö. 8. táblázat) mérséklődött. A késő császár-

51 Vö. Adamik: i. m. (38. jegyz.) 196 skk. és B. Adamik: The Periodization of Latin: An Old Question Revisited. In: Latin Linguistics in the Early $21^{\text {st }}$ Century: Acts of the $16^{\text {th }}$ International Colloquium on Latin Linguistics, Uppsala, June $6^{\text {th }}-11^{\text {th }}, 2011$. Ed. G. Haverling Uppsala 2015. 640-652; 647-648. 
korban, amikor a vulgáris latin nyelvfejlődés nagy lendülettel bontakozott ki, a mássalhangzó előtt bekövetkező $s$-leesés (81\%) és $s$-megtartás (71\%) között az $s$-leesés javára kimutatható különbség összbirodalmi szinten, a kora császárkorhoz képest emelkedett, mégpedig 11\%-ra. A kései Észak- és Dél-Itália (Rómán kívüli) területein ez a különbség még jelentősebb mértékben, 23\%-ra (vö. 9. táblázat), illetve 20\%-ra (vö. 10. táblázat) növekedett.

Mindezek az eredmények igazolják feltevésünket, miszerint a mássalhangzós környezet fontos szerepet játszott a szóvégi $s$ leesésében, különösen és fokozott mértékben a kései korszakban. Ugyanezek az eredmények azonban cáfolják másik feltevésünket, miszerint ez a kései latin feliratokon egyre gyakoribb, mássalhangzó előtti $s$-leesés és az ismert újlatin/román nyelvföldrajzi, $s$-elvesztő keleti újlatin/román és $s$-megtartó nyugati újlatin/román nyelveket és dialektusokat (az ún. Massa-Senigallia-vonal mentén) elkülönítő tagolódás között közvetlen összefüggés lett volna. Az újlatin dialektológiai „törésvonallal” egybeeső ókori provinciahatárok mentén ugyanis ilyen típusú különbség nem mutatható ki: a kései korszakban az $s$-megtartással szemben az $s$-leesés javára kimutatható különbség ugyanis azonos nagyságrendű Észak-Itáliában (23\%) és Dél-Itáliában (20\%), ráadásul némileg, 3\%-kal magasabb a későbbi (újlatin/román kori) $s$-megtartó Észak-Itáliában, ${ }^{52}$ mint a későbbi $s$-elvesztő Dél-Itáliában. Ez a 3\%-nyi különbség azonban hibahatáron (4\%) belüli, így messzemenő következtetéseket nem szabad belöle levonni.

Úgy tünik, hogy az $s$-megtartással szemben az $s$-leesés javára a kora császárkor és késő császárkor között kimutatható növekmény, amely összbirodalmi szinten 4\% (6\% > $10 \%)$, Észak-Itáliában $11 \%$ (12\% > 23\%), Dél-Itáliában pedig $9 \%(11 \%>20 \%)$ volt, nem áll összefüggésben a nominativus és accusativus egybeolvadásával. Ennek az esetfúziónak az aránya ugyanis összbirodalmi szinten igen alacsony (2\%) volt mindkét vizsgált császárkori időszakban (vö. 2. táblázat); ez az arány Észak-Itáliában 3\%-ról (1 előfordulás) 1\%-ra (2 előfordulás) csökkent, Dél-Itáliában pedig 2\%-ról (2 előfordulás) 5\%-ra (3 elöfordulás) növekedett a két korszak között, ami azt jelenti, hogy Itália nem sokban ütött el az összbirodalmi átlagtól. Ettől függetlenül, amint Herman felhívta rá a figyelmet, általánosabb érvek is valószínűtlenné teszik, hogy a szóvégi $s$ leesése összefüggésben állt volna a nominativus és accusativus egybeolvadásával: ez az esetfúzió ugyanis nemcsak azokon az újlatin/román nyelvterületeken következett be, ahol az -s ejtése megszünt, mint a keleti román típusú nyelvekben (román, olasz), hanem ott is, ahol az $-s$ megmaradt, mint a nyugati típusú (pl. az ibéroromán) nyelvekben..$^{53}$

52 Ahogy erre G. Rohlfs: Historische Grammatik der italienischen Sprache und ihrer Mundarten 1. Lautlehre. Bern 1949. 308 rámutat, a szóvégi -s az északolasz dialektusokból csak a középkor folyamán veszett ki mindmáig tartó nyomokat hagyva maga után, vö. A. Zamboni: Contributo allo studio del latino epigrafico della X Regio Augustea (Venetia et Histria). Fonetica (vocali in iato e consonantismo). AIV 126, 118, 144. jegyz.

53 Vö. J. Herman: À propos du débat sur le pluriel des noms italiens (et roumains): à la recherce d'une conclusion. In: Italica et Romanica. Ferstschrift für Max Pfister zum 65. Geburststag. Eds. G. Holtus - J. Kramer - W. Schweickard. Tübingen 1997. 24. 
Mindezekből tehát arra következtethetünk, hogy az -s ejtésének megszűnése a keleti román típusú nyelvekben csak a VII. század után következhetett be vagy a latinromán átmeneti időszakban, vagy már a korai román/újlatin nyelvállapot idején. A szóvégi $s$ elvesztésének folyamatát a keleti típusú román/újlatin nyelvekben feltehetőleg radikális morfológiai innovációk indíthatták be, mint amilyen a harmadik deklinációs névszók többes nominativusi - es végződésének - $i$ szuffixummal történő lecserélése volt (pl. román munți és olasz monti egy *monti, míg a spanyol, portugál montes a montes folyománya stb.). ${ }^{54} \mathrm{Az}$ ilyen és ehhez hasonló morfológiai újítások radikálisan lecsökkenthették a szóvégi $s$-ek gyakoriságát, és egyúttal felerősíthették a fonoszintaktikailag determinált $s$-törlési hajlamot a korai keleti román/újlatin nyelvekben: az eredmény itt a teljes $s$-elvesztés volt. Ezzel szemben a nyugati típusú román/újlatin nyelvekben hasonlóan radikális, de ellentétes hatású morfológiai újítások éppen az -s általános gyakoriságát növelhették meg, pl. az első deklináció többes nominativusi (eredeti -ae helyébe lépő) - as végződésének általánossá válásával (mint pl. a francia chèvres, spanyol és portugál cabras a capras folytatása, míg a román és olasz capre a caprae tulajdonképpeni megfelelője). ${ }^{55} \mathrm{Ez}$ a folyamat marginalizálhatta a fonoszintaktikailag determinált $s$-törlési hajlamot, és stabilizálhatta a szóvégi $-s$ helyzetét, így az $-s$ megmaradt a nyugati típusú román/újlatin nyelvekben.

Noha ezt az egész problémakört kimerítően tárgyalni és minden felmerült kérdést itt megválaszolni nem lehetséges, összegzésképpen mégis levonhatjuk a következő konklúziókat. A fonoszintaktikailag determinált, rákövetkező mássalhangzó előtt bekövetkező szóvégi $s$-törlés mindvégig létezett a latin nyelv történetében, és azt semmiféle standardizációs, normalizációs folyamat nem tudta végérvényesen megszüntetni. Ezt a helyzetet örökölhették meg az újlatin/román nyelvek, amelyekben különböző irányú, komplex morfológiai újítások vezethettek a fonoszintaktikailag meghatározott $s$-törlés megszünéséhez és a szóvégi - $s$ stabilizációjához (amint ez az ún. nyugati újlatin/román nyelvekben bekövetkezett) vagy kiteljesedéséhez és a szóvégi -s teljes eltünéséhez (ahogy ez az ún. keleti típusú újlatin/román nyelvekben történt).

\section{SUMMARY}

The present study deals with the problem of the deletion of word-final $-s$ as evidenced in Latin inscriptions of the Empire. By reconsidering all items of the omission of $-s$ recorded to date in the Computerized Historical Linguistic Database of Latin Inscriptions of the Imperial Age, the morphosyntactic explanation

54 Az olasz többes szám nominativusi végződések eredetének problémájához vö. J. Herman: i. m. (53. jegyz.); A. Zamboni: Alle origini dell'italiano. Dinamiche e tiplogie della transizione dal latino. Roma 2000. 189-197 és V. Faraoni: La formazione del plurale italo-romanzo nella documentazione notarile altomedievale. In: Latin Vulgaire - Latin Tardif X: Actes du X colloque international sur le latin vulgaire et tardif, Bergamo, 5-9 septembre 2012, Tome 1. Eds. P. Molinelli - P. Cuzzolin - P. Fedriani. Bergamo 2014. 99-117.

55 Az olasz - $e$ végződés ugyan nem minden esetben megy vissza közvetlenül a latin -ae végződésre, vö. Herman: i. m. (53. jegyz.) 26-27, de ez nem változtat a végeredményen, az általa kiváltott hatások bekövetkeztének elkerülhetetlenségén. 
proposed by József Herman as for relevant omissions will be replaced by a phonetic and phonosyntactic approach which evidences the all-time prevalence of the consonantal environment in the omission of word final $-s$. Accordingly, the phonosyntactically determined deletion of word final $-s$ before a subsequent consonant existed continuously but to various degrees from the Old Latin age onward all along the history of Latin. This situation might have been inherited by the Romance languages, where different and complex morphological innovations led either to the discontinuation of the phenomenon of phonosyntactically determined deletion and the stabilization of word final $-s$ (as in Western Romance), or to the completion of the deletion process and the complete loss of word final $-s$ (as in Eastern Romance).

Keywords: Inscriptions; phonology; word-final consonants; Old Latin; Vulgar Latin; Western and Eastern Romance

\author{
ADAMIK BÉLA \\ MTA NyTI 'Lendület' Számítógépes Latin Dialektológiai Kutatócsoport \\ ELTE BTK Ókortudományi Intézet Latin tanszék \\ adamik.bela@nytud.mta.hu \\ adamik.bela@btk.elte.hu
}

